\title{
Seroprevalence of hepatitis A antibodies in relation to social factors - a preliminary study
}

\section{KSH de Silva' ${ }^{1}$ DC Weerasuriya ${ }^{2}$, Mallika Peelawattage ${ }^{3}$ and Sirimali Fernando ${ }^{4}$}

(Index words: Children, hepatitis A infection, hospital based study, Sri Lanka, seroprevalence of antibodies)

\begin{abstract}
Introduction Hepatitis A is a benign illness in children with the rare possibility of fatal complications. Although an endemic disease, very few studies have been done in children regarding the seroprevalence of hepatitis $A$ antibodies in Sri Lanka.
\end{abstract}

Objectives (i) To document the seropositivity for hepatitis A in a group of children admitted to a paediatric ward. (ii) To determine the relationship of hepatitis $\mathrm{A}$ viral infection to social factors in these children.

Method A prospective, descriptive, cross-sectional study was carried out in a ward at the Lady Ridgeway Hospital for 7 months from September 2001. Children admitted on predetermined days, needing venepuncture for their presenting illness, were studied while those who were seriously ill were excluded. Written consent was obtained and a questionnaire with details of socio-economic conditions, personal hygiene practices of the mother, access to water and sanitation and health related behaviour was administered. Total antibodies to hepatitis A were detected by ELISA on a sample of blood taken from each patient.
Results Two hundred and eighty eight samples of blood were analysed. None of the children were immunised against hepatitis $A$. There were 158 boys (54.9\%). Thirty one $(10.8 \%)$ of the 288 patients had antibodies against hepatitis $\mathrm{A}$. The seroprevalence was $11.6 \%$ in children under 10 years of age.

Majority $(78 \%)$ were from families with a monthly income of less than Rs 10,000/-. Fifteen (48.4\%) of the 31 seropositive children were from families earning less than Rs 5000/- per month. Belonging to social classes IV and $\mathrm{V}$ and having mothers with only primary education were factors significantly associated with seropositivity. No significant difference in the presence of antibodies was observed regarding the personal hygiene practices analysed and access to basic amenities.

Health related behaviour practices analysed were significantly associated with the presence of hepatitis A antibodies.

Conclusions Seroprevalence of $10.8 \%$ was observed in a selected group of children. Factors such as poor socioeconomic background and having mothers with only primary education were associated with hepatitis A virus

${ }^{1}$ Senior Lecturer, Department of Paediatrics, Faculty of Medicine, Colombo; ${ }^{2}$ Medical Officer, Lady Ridgeway Hospital, Colombo; ${ }^{3}$ Staff grade Technical Officer, Department of Microbiology, Faculty of Medical Sciences, Sri Jayawardenapura; ${ }^{4}$ Professor and Head, Department of Microbiology, Faculty of Medical Sciences, Sri Jayawardenapura Correspondence: KSH de S, e-mail: <shamyadesilva@hotmail.com> (Competing interests: none declared). Received 14 June 2004 and accepted 30 July 2004. 
(HAV) antibodies as were certain health related behaviour practices of children.

\section{Introduction}

Hepatitis A is endemic in Sri Lanka. There are no recent publications on the seroprevalence, but the incidence has shown a progressive decline over the years (Table 1). It is a benign illness in children with a rare possibility of fatal complications. When infected with the hepatitis A virus (HAV), the body responds by producing antibodies. The IgG antibodies thus produced last for a long period and its presence in the serum indicates past infection with HAV. Anti-HAV antibodies can, therefore, be assessed to study the seroprevalence of hepatitis A. An effective vaccine, which is not included in the national schedule, is available in Sri Lanka. Neither its need nor its cost effectiveness in preventing hepatitis A in this country has, however, been assessed.

Table 1. Trends in hospitalisation and hospital deaths of viral hepatitis*

\begin{tabular}{ccc}
\hline Year & $\begin{array}{c}\text { Cases per 100000 } \\
\text { population }\end{array}$ & $\begin{array}{c}\text { Deaths per 100000 } \\
\text { population }\end{array}$ \\
\hline 1975 & 109.8 & 1.4 \\
1980 & 31.7 & 0.4 \\
1985 & 41.9 & 0.4 \\
1990 & 40.9 & 0.4 \\
1995 & 38.7 & 0.1 \\
2000 & 26.3 & 0.1 \\
2001 & 22.5 & 0.2 \\
\hline
\end{tabular}

* Annual Health Bulletin 2001. Source: Medical Statistics Unit

\section{Method}

The study was carried out in the University Unit of the Lady Ridgeway Hospital for 7 months from September 2001. Ethical clearance was obtained from the Ethics Committee of the University of Colombo. Children admitted on predetermined days, needing venepuncture for their presenting illness, were eligible for the study while those who were seriously ill were excluded.

Written consent was obtained from the parents/ guardian after a detailed explanation of the study and its implications for their child.

A questionnaire that sought details of socioeconomic conditions, personal hygiene practices of the mother, access to water and sanitation and health related behaviour of the child was administered by two investigators. $2 \mathrm{cc}$ of blood was taken in a screw-capped bottle from each patient at the time of venepuncture for other investigations and refrigerated in a separate container. These were delivered to the laboratory at the Sri Jayawardenapura University. The serum was separated and the samples refrigerated at
$4^{0} \mathrm{C}$ till the test was performed. Bio ELISA HAV total antibody test kits were used to detect the presence of total antibodies to hepatitis A.

\section{Results}

Of the 304 samples of blood collected, only 288 samples were suitable for analysis. None of the children had been immunised against hepatitis A. There were 158 boys $(54.9 \%)$ and 130 girls $(45.1 \%)$. Two hundred forty three $(84.4 \%)$ patients were from the Western Province.

Thirty one $(10.8 \%)$ of the 288 patients had antibodies against hepatitis A; there were 16 boys and 15 girls. Seven of the $31(22.6 \%)$ patients had clinical features of viral hepatitis on admission and two gave a past history of jaundice. The prevalence of hepatitis A antibodies in relation to the sociodemographic features of the study sample are given in Table 2 . Of the 242 patients under 10 years of age, 28 had antibodies to hepatitis A (11.6\%). Majority of the children in the study (78\%) were from families with a monthly income of less than Rs 10 000/-. Of the 31 children who were seropositive, 15 (48.4\%) were from families earning less than Rs $5000 /-$ per month. The social class of the patients was classified according to their fathers' occupation [1]. Twenty two of the 31 antibody

Table 2. Sociodemographic features of the study sample in relation to the presence of hepatitis $A$ antibodies in the child

\begin{tabular}{|c|c|c|}
\hline & $\begin{array}{c}\text { Hep } A+v e \\
\text { number }\end{array}$ & $\%$ positivity \\
\hline \multicolumn{3}{|l|}{ Age distribution } \\
\hline$<1$ year $(\mathrm{n}=16)$ & 0 & - \\
\hline $1-5$ years $(n=141)$ & 12 & 8.5 \\
\hline $5-10$ years $(n=85)$ & 16 & 18.8 \\
\hline $10-12$ years $(n=22)$ & 3 & 13.6 \\
\hline$>12$ years $(n=24)$ & 0 & - \\
\hline \multicolumn{3}{|l|}{ Monthly family } \\
\hline \multicolumn{3}{|l|}{ Income (Rs) } \\
\hline$<5000(\mathrm{n}=111)$ & 15 & 13.5 \\
\hline $5000-10000(\mathrm{n}=114)$ & 11 & 9.6 \\
\hline$>10000-20000(n=47)$ & 05 & 10.6 \\
\hline$>20000(\mathrm{n}=16)$ & 0 & - \\
\hline \multicolumn{3}{|l|}{ Social class" } \\
\hline $\mathrm{I}(\mathrm{n}=07)$ & 0 & - \\
\hline II $(\mathrm{n}=59)$ & 04 & 6.8 \\
\hline III $(n=103)$ & 05 & 4.9 \\
\hline IV $(n=56)$ & 09 & 16.1 \\
\hline$V(n=63)$ & 13 & 20.6 \\
\hline \multicolumn{3}{|l|}{ Mothers' education } \\
\hline No education $(\mathrm{n}=05)$ & 02 & 40.0 \\
\hline Grade $1-5(n=22)$ & 05 & 22.7 \\
\hline Grade $6-10(n=163)$ & 14 & 8.6 \\
\hline Grade $11-12(n=83)$ & 09 & 10.8 \\
\hline Higher education $(\mathrm{n}=15)$ & 01 & 6.7 \\
\hline
\end{tabular}

23 patients had thalassaemia; II According to fathers' occupation 
positive children $(71 \%)$ were from social classes IV and V while none were from social class I.

A statistically significant difference in the HAV seropositivity was observed in children from lower social classes (IV and V) and who had mothers having had only a primary education (Table 3 ). When the availability of basic amenities were compared with the presence of antibodies (Table 4), there was no significant difference in the seroprevalence between the children who had their own source of water and toilet facilities and those who shared with others. Disposal of garbage conducive to fly breeding was not significantly associated with the presence of antibodies in this study. Mother prepared the food of 271 children (94\%) and all except two used soap to wash their hands. Table 5 is an analysis of the personal hygiene practices of the mothers/ bystanders. There was no statistically significant difference in the practices analysed with the presence of antibodies.

Health related behaviour in relation to seroprevalence of antibodies is given in Table 6. Drinking unboiled water and eating from places other than home were significantly associated with the presence of hepatitis A antibodies in these children.

\section{Discussion}

Seroprevalence of hepatitis A (HAV) antibodies in developing countries is reported to be $100 \%$ by 5 years of age [2]. In the present study, $10.8 \%(31 / 288)$ of the patients had anti-HAV antibodies. Only 9 out of 31 (29\%) seropositive patients had or gave a history of symptomatic hepatitis, confirming that asymptomatic infection is commoner in children [2].

According to the epidemiological classification of HAV endemicity [3], high endemicity is defined as an antiHAV antibody prevalence of $>80 \%$ by the age of 10 years. According to a WHO/SEARO report of 2000, Bangladesh, India, Maldives, and Nepal are countries with high hepatitis A endemicity. The report states that $85-95 \%$ of the children in these countries become immune to the disease by 10 years of age [4]. In the USA, however, only a $10 \%$ seroprevalence for HAV is seen in children $<10$ years of age [3], whereas $30-40 \%$ of the adult population is

Table 3. Significance of social factors in relation to the prevalence of hepatitis A antibodies in the child

\begin{tabular}{|c|c|c|c|}
\hline Socialfactor & Hep A +ve number & $\%$ positivity & $\begin{array}{l}\text { Statistical } \\
\text { significance }\end{array}$ \\
\hline \multicolumn{4}{|l|}{ Monthly family income (Rs) } \\
\hline$<10,000(\mathrm{n}=225)$ & 26 & 11.6 & $\mathrm{p}=0.4$ \\
\hline$\geq 10,000(\mathrm{n}=63)$ & 05 & 7.9 & \\
\hline \multicolumn{4}{|l|}{ Social class"II } \\
\hline I-III $(\mathrm{n}=169)$ & 09 & 5.3 & $\mathrm{p}=0.0008$ \\
\hline IV and $V(n=119)$ & 22 & 18.5 & \\
\hline \multicolumn{4}{|l|}{ Mothers' education } \\
\hline Primary education $(\mathrm{n}=27)$ & 07 & 25.9 & $p=0.04$ \\
\hline Secondary and tertiary education $(n=261)$ & 24 & 9.2 & \\
\hline
\end{tabular}

II According to fathers' occupation.

Table 4. Environmental factors in relation to the presence of hepatitis $A$ antibodies in the child

\begin{tabular}{|c|c|c|c|}
\hline $\begin{array}{l}\text { Environmental } \\
\text { factor }\end{array}$ & $\begin{array}{c}\text { Hep A +ve } \\
\text { number }\end{array}$ & $\%$ positivity & $\begin{array}{r}\text { Statistical } \\
\text { significance }\end{array}$ \\
\hline \multicolumn{4}{|l|}{ Source of water } \\
\hline Own $(\mathrm{n}=236)$ & 22 & 9.3 & $\mathrm{p}=0.14$ \\
\hline Public $(\mathrm{n}=52)$ & 09 & 17.3 & \\
\hline \multicolumn{4}{|l|}{ Toilet facilities } \\
\hline Own $(\mathrm{n}=217)$ & 23 & 10.6 & $\mathrm{p}=0.8$ \\
\hline Public $(\mathrm{n}=71)$ & 08 & 11.3 & \\
\hline \multicolumn{4}{|l|}{ Faecal soiling of sand } \\
\hline Absent $(n=214)$ & 23 & 10.7 & $\mathrm{p}>0.05$ \\
\hline Present $(n=74)$ & 08 & 10.8 & \\
\hline \multicolumn{4}{|l|}{ Presence of flies* } \\
\hline No $(n=192)$ & 19 & 9.9 & $\mathrm{p}=0.4$ \\
\hline Yes $(n=96)$ & 12 & 12.5 & \\
\hline
\end{tabular}

* Presence or absence of flies as reported by the bystander.
Table 5. Personal hygiene practices of the mother/bystander in relation to the presence of hepatitis $A$ antibodies in the child

\begin{tabular}{lccc}
\hline Practice & $\begin{array}{c}\text { Hep A }+v e \\
\text { number }\end{array}$ & \% positivity & $\begin{array}{c}\text { Statistical } \\
\text { significance }\end{array}$ \\
\hline Proper handwashing & & & \\
$\quad$ Yes ( $\mathrm{n}=187)$ & 19 & 10.2 & $\mathrm{p}=0.6$ \\
$\quad$ No $(\mathrm{n}=101)$ & 12 & 11.9 & \\
Trimmed fingernails & & & \\
$\quad$ Yes ( $=136)$ & 13 & 9.6 & $\mathrm{p}=0.4$ \\
$\quad$ No $(\mathrm{n}=152)$ & 18 & 11.8 & \\
Dirty nails & & & \\
$\quad$ No $(\mathrm{n}=164)$ & 13 & 7.9 & $\mathrm{p}=0.08$ \\
$\quad$ Yes $(\mathrm{n}=124)$ & 18 & 14.5 & \\
\hline
\end{tabular}


seropositive [2] . A study published in 2000 from Delhi, India reported a prevalence of anti-HAV antibodies of $80 \%$ by 5 years of age, the most vulnerable age group being 0.5 to 1.5 years [5]. But a study from Punjab, India, carried out in 2001, demonstrated $5.5 \%$ prevalence of HAV antibodies, affecting mostly children below 14 years [6].

Table 6. Health related behaviour in relation to the presence of hepatitis A antibodies

\begin{tabular}{lcrc}
\hline Practice & $\begin{array}{c}\text { Hep A +ve } \\
\text { number }\end{array}$ & positivity & $\begin{array}{c}\text { Statistical } \\
\text { significance }\end{array}$ \\
\hline Disposal of faeces & & & \\
$\quad$ Toilet $(\mathrm{n}=248)$ & 26 & 10.5 & $\mathrm{p}=0.6$ \\
$\quad$ Elsewhere $(\mathrm{n}=40)$ & 05 & 12.5 & \\
Drinking water & & & \\
$\quad$ Boiled ( $=112)$ & 07 & 6.3 & $\mathbf{p}=\mathbf{0 . 0 2}$ \\
$\quad$ Unboiled ( $=176)$ & 24 & 13.6 & \\
Food consumption & & & \\
$\quad$ Home prepared $(\mathrm{n}=115)$ & 05 & 4.3 & $\mathbf{p}=\mathbf{0 . 0 0 1}$ \\
$\quad$ Other (n=173) & 26 & 15.0 & \\
\hline
\end{tabular}

Relatively low prevalence rates have been reported from Bangkok, Thailand, in years 1998/99 which state an overall $12.4 \%$ prevalence of HAV IgG. The prevalence in the various age groups up to 16 years was low with the highest rate of $25.9 \%$ found in the age group 16-30 years [7]. Low seroprevalence has also been reported from Cyprus with no positives in the 6-12 years and a prevalence of only $1.6 \%$ in the age group of 13-18 years [8]. A study from Turkey, however, reported an overall prevalence of anti-HAV of $33.1 \%$ in children with the seropositivity rates being $19.9 \%$ and $43.9 \%$ in preschool and schoolchildren, respectively [9]. A study from Netherlands, however, had reported an overall prevalence of $33.8 \%$ with a seroprevalence of $<10 \%$ under 35 years [10].

An islandwide general population survey done in 1976 in Sri Lanka had shown an overall anti-HAV antibody prevalence of $76.4 \%$ with the rates increasing with age $[11,12]$. A similar trend of increased seroprevalence with advancing age has been reported from other countries throughout the world $[7,10,13,14]$. The present study demonstrated an overall seropositivity of $10.8 \%$ with $8.5 \%$ in the $1-5$ years' and $18.8 \%$ in the 5-10 years' age groups. This is in contrast to the high rates of $26.6 \%$ and $55.9 \%$ reported previously in similar age groups (Table 7). A similar change in the epidemiological pattern over the years with a reduction in the overall seroprevalence [15] and a reduction in the seropositivity in the younger population have been reported from India [16].

The known associations with HAV infection have been demonstrated in various studies, which have reported an increased prevalence of HAV antibodies with low socioeconomic status, inadequate maternal education and unsatisfactory drinking water [5,15,17]. Tables 3 and 6 demonstrate similar associations in the present study.
Table 7. Anti-HAV antibody prevalence in children up to

10 years-comparison of results of 1976 survey with the present study

\begin{tabular}{lcccc}
\hline $\begin{array}{l}\text { Age group } \\
\text { (years) }\end{array}$ & $\begin{array}{c}\text { Present study (2001/2002) } \\
\text { No: }+ \text { ve for/No: tested } \\
\text { anti-HAV* }(\%)\end{array}$ & $\begin{array}{c}\text { No: }+ \text { ve for/No: tested } \\
\text { anti-HAV** }\end{array}$ \\
\hline$<1$ & $0 / 16$ & $(0)$ & $0 / 10$ & $(0)$ \\
$1-5$ & $12 / 141$ & $(8.5)$ & $17 / 64$ & $(26.6)$ \\
$5-10$ & $16 / 85$ & $(18.8)$ & $38 / 68$ & $(55.9)$ \\
\hline
\end{tabular}

* Total anti-HAV antibodies by ELISA

** Anti-HAV Ig G by RIA

${ }^{11,12}$ See references 11 and 12.

\section{Conclusions}

This study demonstrated a $10.8 \%$ seroprevalence of hepatitis A antibodies in a selected group of children. It showed that children coming from a poor socioeconomic background and having mothers with only primary education, were more likely to get infected, confirming reports from countries the world over. Of the social factors, behaviour patterns and health related practices analysed, presence of hepatitis A antibodies was significantly associated with drinking unboiled water and eating food cooked in places other than home.

It is also observed that the seroprevalence in children has decreased over the years in Sri Lanka and the data from this study would suggest that, although a developing country, our anti-HAV antibody rates are comparable to the western countries.

\section{Recommendations}

Recommendations based on this study would be to educate the mothers and children on the importance of drinking boiled water and eating hygienically prepared food to prevent hepatitis A infection.

Community based, islandwide, age stratified, large scale studies with morbidity and mortality patterns are necessary before any recommendations can be made regarding a national policy for vaccination.

\section{Acknowledgements}

This study was possible due to the financial grant by the University of Colombo (Project number: AP/3/2/ 99/M/18).

\section{References}

1. Abramson JH. Survey Methods in Community Medicine. 4th ed. London: Churchill Livingstone, 1990.

2. Snyder JD, Pickering LK. Viral hepatitis. In: Behrman RE, Kliegman RM, Jenson HB eds. Nelson Textbook of Paediatrics. 17th ed. Pennsylvania: Saunders, 2004: 1324-7. 
3. Prevention of Hepatitis A through active or passive immunization: Recommendation of the Advisory Committee on Immunization practices. MMWR 45(RR15);1996: 1-30.

4. WHO/SEARO. Women of South-East Asia: A Health Profile. Regional Publications, SEARO No. 34, 2000.

5. Dutta AK, Aggarwal Akapoor AK, Ray GN, Batra S. Seroepidemiology of hepatitis A in Delhi. Indian Journal of Pediatrics 2000; 67: 77-9.

6. Kaur H, Oberoi A, Chander R, Pawar G, Verma M. Epidemiology of hepatitis $\mathrm{E}$ and A in Ludhiana. Tropical Gastroenterology 2002; 23: 76-8.

7. Pancharoen C, Mekmullika J, Kasempimolporn S, Thisyakorn U, Wilde H. Seroprevalence of hepatitis A virus antibody among children and young adults in Bangkok. Journal of Medical Association of Thailand 2001; 84: 1477-80.

8. Hadjipanayis A, Hadjichristodoulou C, Kallias M, Sava K, Petsa A, et al. Prevalence of antibodies to hepatitis A among children and adolescents in Larnaca area, Cyprus. European Journal of Epidemiology 1999; 15: 903-5.

9. Colak D, Ogunc D, Gunseren F, Velipasaoglu S, Aktekin MR, et al. Seroprevalence of antibodies to hepatitis A and E viruses in pediatric age groups in Turkey. Acta Microbiologica et Immunologica Hungarica 2002; 49: 93-7.

10. Termorshuizen F, Dorigo-Zetsma JW, de Melker HE, van den Hof S, Conyn-Van Spaendonck MA. The prevalence of antibodies to hepatitis A virus and its determinants in
The Netherlands: a population-based survey. Epidemioogy and Infection 2000; 124: 459-66.

11. Vitarana T, Kanapathipillai M, Gunasekera HDN, Lehmann NI, Dimitrikakis M, et al. Seroepidemiological study of hepatitis A and hepatitis B infection in Sri Lanka. Asian Journal of Infectious Diseases 1978; 2: 247-52.

12. Vitarana T. Viral hepatitis in Sri Lanka. Ceylon Medical Journal 1989; 34: 163-77.

13. Yapicioglu H, Alhan E, Yildizdas D, Yaman A, Bozdemir N. Prevalence of hepatitis A in children and adolescents in Adana, Turkey. Indian Pediatrics 2002; 39: 936-41.

14. Dentinger CM, Heinrich NL, Beil BP, Fox LM, Katz DJ, et al. A prevalence study of hepatitis A virus infection in a migrant community: Is hepatitis A vaccine indicated? Journal of Pediatrics 2001; 138: 705-9.

15. Arankalle VA, Chadha MS, Chitambar SD, Walimbe AM, Chobe LP, et al. Changing epidemiology of hepatitis A and hepatitis E in urban and rural India (1982-98). Journal of Viral Hepatitis 2001; 8: 293-303.

16. Das K, Jain A, Gupta S, Kapoor S, Gupta RK, et al. The changing epidemiological pattern of hepatitis A in an urban population of India: emergence of a trend similar to the European countries. European Journal of Epidemiology 2000; 16: 507-10.

17 Leach CT, Koo FC, Hilsenbeck SG, Jenson HB. The epidemiology of viral hepatitis in children in South Texas: increased prevalence of hepatitis A along the Texas-Mexico border. Journal of Infectious Diseases 1999; 180: 509-13. 